\title{
SPTLC1 Gene
}

National Cancer Institute

\section{Source}

National Cancer Institute. SPTLC1 Gene. NCI Thesaurus. Code C127888.

This gene plays a role in lipid modification. 